\title{
TWO MODELS OF RADICAL REVELATION IN AUSTRIAN PHILOSOPHY
}

\author{
BALAZS MEZEI \\ Peter Pazmany Catholic University
}

\begin{abstract}
In this paper I highlight two opposing models of the notion of divine revelation: the propositional and the radical. The propositional understanding of revelation was central to theology and philosophy until the rath century. Since then, a number of other models of revelation have emerged. I define as radical the understanding of revelation which emphasizes two features of revelation: I) God's existence is *per se* revelatory; 2) God's revelation is *per se* self-revelation. I propose too an assessment of the notion of propositional revelation as presented by Richard Swinburne. And I offer detailed analyses of two representatives of the early understanding of divine revelation as self-revelation: the views of Bernard Bolzano and Anton Günther. Bolzano, the renowned mathematician, was also a philosopher of religion; and Günther, one of the most ingenious writers in Austrian philosophy, was not only a theologian but also a philosopher comparable to the important figures of igth century German thought. ${ }^{1}$
\end{abstract}

\section{INTRODUCTION}

The expression "divine revelation" is traditionally considered as belonging to the vocabulary of Christian theology. According to theologians, divine revelation is the most fundamental theological notion without which no other theological concept can be properly understood and explicated. ${ }^{2}$ Theological consideration of the concept of revelation, that is to say a theology of revelation, is therefore a fundamental discipline,

\footnotetext{
${ }^{1}$ I express my gratitude to Tom Flint, Fred T. Crosson, and to other members of the Center for Philosophy of Religion at the University of Notre Dame for their helpful comments on the first version of the present text. I thank Richard Swinburne too for his important and useful remarks.

${ }^{2}$ Josef Schmitz, Offenbarung (Düsseldorf: Pathmos, I988), ıо.
}

European Journal for Philosophy of Religion i (2009), PP. 99-I20 
which systematically determines the building of theology. ${ }^{3}$ On the other hand, a theology of revelation cannot merely consist of arguments based on supernatural revelation. Fundamental theology is first of all a philosophical discipline, for its methods and contents are based on what is traditionally termed unassisted, as opposed to supernaturally enlightened, human reason. A fully developed theology of revelation thus starts with the philosophy of divine revelation.

Just as the structure of a theology of revelation is dual, containing both introductory and higher level theological considerations, so too the philosophy of revelation has a twofold structure. While it can be conceived of as an introduction to theology properly so called, it is at the same time a philosophical discipline in its own right. ${ }^{4} \mathrm{We}$ can even say that a philosophy of revelation is the preeminent philosophical discipline inasmuch as it deals with the ultimate sources of human knowledge. According to the traditional understanding of theological propaedeutics, a merely philosophical approach to the problem of divine revelation consists in demonstrating the possibility, necessity, and discernability of revelation. As revelation entails the revealing subject, God, thus the philosophy of revelation - or at least some part of it-argues in due course for the existence and attributes of such a God. ${ }^{5}$ There is also the important question, if there is a God Who reveals important information to certain persons, what kind of recipient is needed in order to be able to receive divine revelation? The question of the conditions of possibility for the human reception of divine revelation is for many authors the decisive philosophical question in a philosophy of revelation. ${ }^{6}$

I define the expression "divine revelation" as an act of God by which some uniquely significant information becomes accessible for a certain number of human and non-human persons concerning their origin, present situation, and future; as well as concerning the reality they live

${ }^{3}$ Reginald Garrigou-Lagrange, De revelatione per Ecclesiam Catholicam proposita (Torino: Marietti, I944), I, x-xi; Rene Latourelle, Theology of Revelation (New York: Alba House, I966).

${ }^{4}$ In the Introduction to Models of Revelation, Dulles defines his approach to the problem of revelation as belonging to the realm of fundamental theology, that is to say philosophy.

${ }^{5}$ Peter Eicher, Offenbarung. Prinzip neuzeitlicher Theologie (München: Kosel, 1977), 507.

${ }^{6}$ Karl Rahner, Foundations of the Christian Faith (New York: Crossroad, I989). 
in and know to a certain extent. ${ }^{7}$ The God of classical theism is such that any of His acts counts as a certain kind of revelation, inasmuch as an act of God is an act of an infinite and absolute being Who, by acting, reveals His infinity and absoluteness. As we shall see, the concept of divine revelation proves to be a complicated one, and the above definition serves as a preliminary orientation only.

A history of the concept of revelation should emphasize that it was in response to the naturalistic and rationalistic tendencies of the Enlightenment period that systematic theories of revelation of quite different kinds-from J. G. Fichte to the teaching of the First Vatican Council, or from F. D. Schleiermacher to Karl Barth—gradually emerged. Before the First Vatican Council no council or official declaration of the Church dealt with the concept of divine revelation in an articulate way and it was only the Second Vatican Council that issued a thoroughly developed text, that of Dei Verbum, explaining the Catholic standpoint in view of various debates on divine revelation. In both texts, however, the capability of natural, unassisted human reason to recognize the existence of God without divine revelation is clearly propounded.

One central point in the philosophical and theological discussions concerned the nature of divine revelation. For a long time, the Classical understanding of revelation took the term as signifying most importantly God's special actions by which $\mathrm{He}$ communicates some definite truths or propositions in order to inform certain human persons about verities indispensable for their salvation. Such revealed propositions were considered instructions-based on the authority of the Church's magisterium - to be listened to, freely acknowledged and followed by all persons wishing to participate in the divine work of salvation. However, the propositional understanding of revelation (hereafter PR) came to be challenged by a different approach to divine revelation, emphasized by theologians and philosophers seeking new ways to understand divine revelation. They gradually realized the insufficiencies of the notion of propositional revelation especially under the influence of new forms of

\footnotetext{
${ }^{7}$ By 'God' I understand the conception of classical theism. Accordingly, there 'is' an ultimate, absolute and infinite, and in some sense personal being who has created reality in its totality by the act of his free will, who maintains this reality and takes care of it in a complex fashion, a being referred to as 'God' in the English language.
} 
thought originating in the Kantian critique of traditional theology in the Critique of Pure Reason. ${ }^{8}$

Let me term the other understanding of divine revelation radical revelation (hereafter $\mathrm{RR}$ ). I call this kind of revelation radical for two reasons. First, it sees God's reality as revelatory per se; God's reality, on this view, is self-revelatory. Second, divine revelation is not considered as an activity of God resulting in a set of propositional truths, but rather as disclosing (manifesting or revealing) what God is in Himself, in a way that cannot be termed propositional in its genuine form. RR can properly be called God's self-revelation. There are various ways to construe what God's self-revelation consists in, but the way pointed out, for instance, in Dei Verbum - namely that God's self-revelation is His historical action-seems to be the most widely accepted view. This is not to say that divine revelation, as God's self-revelation, cannot be conceived of in a different way; as an example of another approach I shall investigate Anton Günther's view below.

Although it was F.W.J. Schelling, and following him G.W.F.Hegel, who invented and introduced the expression 'self-revelation'(Selbstoffenbarung) as a technical term into the philosophical and theological discussions of the $19^{\text {th }}$ century, the notion had been present in various works before that time. ${ }^{9}$ The German word for revelation, Offenbarung, was especially apt to give the term a broad meaning. Offenbarung means, literarily, 'disclosing' or 'manifesting'. Thus German theologians, by using this word instead of a version of the Latin revelatio (as most European languages do), had a language-based inclination to understand revelation as the most general

${ }^{8}$ See Immanuel Kant, The Critique of Pure Reason (Chicago: Encyclopaedia Britannica, I952), I, II, II, III, VII. Even if the distinction between propositional and non-propositional revelation can be typically identified as traditionally characteristic of the mainstream Catholic and Protestant viewpoints respectively, Keith Ward is right in pointing out that the conception of propositional revelation "is nowhere better set forth than in Calvin's Institutes."Ward offers a detailed and instructive analysis of this difference in Keith Ward, Revelation and Religion (Oxford: Clarendon Press, 1994), 212-232.

9 The English self-revelation was the translation of Selbstoffenbarung and did not appear before the I82os. In German, solid compound forms of selbst and Offenbarung start to surface by the end of the I50os. Selbstoffenbarung in the definite meaning of revealing oneself as oneself was first used, not yet as a technical term, by the $16-\mathrm{I} 7^{\text {th }}$ century German mystic, Jacob Böhme. 
act of God manifesting or disclosing Himself. ${ }^{10}$ Yet the ancient doctrine of the Trinity already shows that various revealed propositions have been latently considered as entailing divine self-revelation. Christianity, by emphasizing the propositional character throughout the centuries, never denied that PR was based in the last analysis on God's self-revelation. ${ }^{11}$ The theological synergy between Christian denominations throughout the $20^{\text {th }}$ century in matters of revelation is well demonstrated by the effects of the radical theory of revelation of Karl Barth on the one hand, and the intricate understanding of revelation offered by Karl Rahner on the other hand.

Divine revelation understood as PR highlights two aspects of revelation: first, the aspect of propositional truths explicit in the Scripture, in the tradition, and in the teachings of the Church. Second, it accentuates the recipient of $\mathrm{PR}$ in terms of the intellectual and volitional functions required for the acceptance of a revelation propositional in character. While divine revelation as PR narrows down the possible scale of God's revealing activity, it also reduces the possibilities of human persons in communicating with God. Thus, PR does not consider divine revelation as an encounter between God and man, nor does it allow features of immediacy in the divine-human relationship. Rather, PR entails a notion of the recipient of revelation as a being possessing especially understanding and will, in order to conceive the propositions and to approve them. On the other hand, the emphasis on propositions goes together with the emphasis on the characteristic warrant of such propositions, that is the authority of the Church.

10 The German Offenbarung was originally the translation of the Greek apokalupsis. Yet the Greek word, itself again a translation of the Hebrew gala, meant simply the removal of a cover. In German, however, the compound is put together from offen (open), and barung (making bare, naked, free). Unintentionally, the German translation introduced a much wider meaning into the traditional meaning of apocalupsis-revelatio.

${ }_{11}$ The explicitly propositional understanding of divine revelation was proposed during the post-Tridentine period, by among others Francisco Suarez. His understanding of revelation shifted the emphasis from the action of God (understood as power) to the action of God (understood as object, see Latourelle, pp. 18I sq.). God's revelation is "the simple and sufficient proposition of the revealed objects" (Latourelle, p. 183.). Avery Dulles considers propositional revelation as one model out of various other models (Dulles I992). 
As opposed to PR, divine revelation understood as RR spells out the radical character of divine revelation. By "radical character," I understand, first, the fact that divine revelation does not merely consist of propositions but rather sets of propositions, that is systems of propositional truths. The unity of such systems however cannot be expressed propositionally; so divine revelation is in the last analysis non-propositional. Second, RR emphasizes that divine revelation is identical with divine action in the various meanings of the term, but primarily with reference to God's activity aimed at fulfilling His intention to realize the economy of salvation. $\mathrm{RR}$ is not confined to the created world; just as the work of salvation is realized by God's revealing His own reality, so too RR refers to God's original activity taken in all the four senses of the term mentioned above. Such a view of RR does not imply that God's absolute and infinite reality can become revealed in its absoluteness and infinity to created beings. It implies, however, that God communicates Himself not only immanently, that is in His absolute and infinite reality, but also with respect to the created world. Inasmuch as RR implies PR in a certain way, RR does not lack propositional truths, whereas its whole significance is given in view of God's full activity.

In what follows I examine two models of divine revelation. In section 2, I consider the model of PR by considering Richard Swinburne's view. In section 3, I develop two versions of the model of RR based on the work of the Austrian philosopher Bernard Bolzano (I78I-I848). Another Austrian philosopher, Anton Günther (I783-I863) develops a different version of RR, which I investigate in section 4. As we shall see, Bolzano offers a weak and Günther a strong version of $R R$.

\section{Propositional Revelation}

In order to explain the characteristics of PR, I make use of Richard Swinburne's view as propounded in Revelation: From Metaphor to Analogy. I have chosen Swinburne's book because he clearly points out that his work is about propositional revelation, while he does not deny the existence 
of another kind of revelation. ${ }^{12}$ Swinburne spells out in detail that some propositions central to divine revelation may be understood in metaphorical or analogical senses, that is in ways not immediately given in the normal use of sentences containing such propositions. His view of $\mathrm{PR}$ is complex and allows a perspicacious interpretation of PR. I shall, however, point out that even his elaborate understanding of PR can be criticized for not taking into account what I term RR. The main point of my criticism consists in this, that $\mathrm{PR}$ cannot be properly investigated without appropriately contemplating the dimension of RR.

Swinburne briefly investigates the distinction between PR and another kind of revelation, God's action in human history. According to Swinburne,

Divine revelation may be either of God, or by God of propositional truth. Christianity has claimed that Christian revelation has involved both of these; God revealed himself in becoming incarnate (i.e. human) as Jesus Christ, and by the teaching of Jesus and the Church which he founded God revealed various propositional truths. My primary concern in this book is with revelation in the secondary sense of revelation of propositional truth." ${ }^{13}$

As becomes clear from the above quotation, Swinburne distinguishes between two basic kinds of revelation: I. The revelation "of God," that is to say of God revealing Himself in the incarnation of Christ. 2. The revelation "by God of propositional truth," which I termed PR above. Swinburne's emphasis is on the second kind, without however denying the existence of further kinds, such as knowledge of God made available to us in private ways, or God's actions in history. He suggests, however, that in his approach the propositional form of revelation remains the main target of investigation. He argues that God's self-revelation or historical actions cannot be properly analyzed in non-propositional terms.

12 The problem of propositional revelation has been considered and analyzed in Terence Penelhum's essay (in: Avis, op. cit. See also Dulles, op. cit.).

${ }^{13}$ Richard Swinburne, Revelation: From Metaphor to Analogy, Second Edition (Oxford: Oxford University Press, 2007), I-2. In the first edition of his book, Swinburne does not speak of God's self-revelation; he only points out that though there are various forms of revelation his concern is with revelation of propositional truth. See Swinburne, Revelation, 1992, 2-3. 
The problem of PR can be seen more clearly if we try to clarify what Swinburne understands by a proposition. He carefully distinguishes between token and type sentences, and defines the proposition as expressed in token sentences:

The proposition which a token sentence s expresses is that element of claim in what is said which is also made by any other token sentence (whether of the same type or not) which is synonymous with s. ${ }^{14}$

A proposition, then, is the meaning of a token sentence, which can be expressed by other token sentences as well. In order to be able to grasp such a meaning, it needs to be in a propositional form, according to Swinburne; that is in a form, which makes it possible to understand the proposition. Thus for instance I can have the same proposition in two token sentences, one in German, the other in English, and if I have a sufficient knowledge of the two languages, I am able to grasp the same proposition in both sentences. A proposition describing some features of God can be grasped in various token sentences, for instance in various languages. In all cases, I grasp the same proposition.

"Grasping the same proposition," however, is not without difficulties in the Christian context. Depending on the meaning of 'grasping' and of similar terms, we can distinguish between a traditional and a rationalistic understanding of certain propositions of Christianity. According to the rationalistic understanding, human beings are able to grasp or understand fully every proposition about God. The traditional understanding, on the other hand, very often refers to the notion of 'mysterium'. Accordingly, there are second order mysteries (mysteria non stricte dicta) which can be grasped or understood fully once they are revealed. Such mysteries can be expressed in propositions that are clear and can be sufficiently grasped by human reason. Such a mystery is, for instance, the doctrine of God's incarnation, which can be argued for once divine incarnation is already an accomplished fact. Thus it can be argued that God, if $\mathrm{He}$ is infinitely good and human beings cannot be helped otherwise, may take a human form in order to manifest His love for human beings and to ensure their salvation.

${ }^{14}$ Swinburne, Revelation, 2007, 8. 
On the other hand, there are first order mysteries (mysteria stricte dicta) which, even if revealed, cannot be fully grasped or understood. The proposition "God is three persons in one substance" is such that its meaning, that is its propositional character, cannot be properly understood by a finite mind. If we define a proposition as what can be grasped or understood fully, then first order mysteries, even if expressed in propositional form, cannot be called propositional strictly speaking. Even if we introduce metaphor and analogy into our understanding of such mysteries, we still face the difficulty that there is a categorical difference between a metaphorical and analogical understanding of certain propositions (such as propositions in literary works) on the one hand, and propositions referring to first order mysteries on the other hand. Propositions referring to first order mysteries cannot be propositionally understood, since the infinite and absolute God-in accordance with the view of classical theism-cannot be fully conceived of, grasped, or understood.

The expression 'mystery' refers first to mysteria stricte dicta. A mystery is precisely such that its meaning cannot be grasped or understood fully. Mysteries considered understandable once revealed are mysteries only in virtue of first order mysteries. God is above all non-understandable, given His absoluteness and infinity; He is the very first "first order mystery." Only because of first order mystery am I able to understand second order mysteries that are derivative of the previous kind. In order to be able to conceive of propositions expressing second order mysteries, I need to have the conception of first order mysteries, that is a conception of divine revelation as possessing the character of such mysteries. Divine revelation is a revelation, of the first order, of first order mysteries. Even if they can be expressed in propositional form, they are not, most importantly of a propositional character.

Let me briefly point out the problem of PR from a different angle. According to Bernard Bolzano (whose concept of revelation will be considered below), one of the most important terms in logic is "proposition as such" (Satz an sich). "Propositions as such" exist ideally in themselves, but can be exemplified in acts of judgment by judging them true or false. Thus in Bolzano's vocabulary 'judgments' (Urteile) more or less amount to what we have termed 'propositions' above. A judgment in Bolzano's definition is a proposition taken to be true or false in an act of judgment, that is to say in a cognitive act. We may say that a judgment 
is a proposition exemplified in the act of any created being. Judgments exemplify propositions as such in various ways, but it is not the case that every proposition as such can be exemplified in judgments. There are propositions as such which we did not, do not, and shall not know; and others we cannot exemplify properly in judgments. In a similar way, a given set of judgments $\mathrm{J}$ is capable of exemplifying a given proposition $\mathrm{p}$ only to a limited extent, and the proposition as such 'p' can never be grasped in its ' $p$ ' character in any or every J entailing $\mathrm{j} \mathrm{j}, \mathrm{j} 2, \mathrm{j} 3 \ldots \mathrm{jn}$. We may thus say that ' $\mathrm{p}$ ' is by no means a judgment, but rather what judgments refer to by exemplifying it. In the last analysis, the set (Inbegriff) 'P' of all propositions as such ('pr', 'p2', 'p3'... 'pn') is not even a proposition as such, but rather, as Bolzano points out, is identical in a certain way with an aspect of God's knowledge.

As Bolzano writes,

The all-knowing God knows not only every true but also every false proposition (Satz). He knows not only those propositions that are taken to be true or conceived of by any created being, but also those which are not taken to be true and are not even conceived of by any creature either now or in the future..$^{15}$

Bolzano's analysis points out that judgments (or Swinburne's propositions) are such that they refer to their own non-propositional dimension. Even if we do not take into account the notion of first and second order mysteries, it seems to be possible to argue that no propositional truth is a self-contained unit of meaning, but refers to greater contexts, in the last analysis to God's mind, which cannot be expressed propositionally in its full extent. If a message $M$ is a unit of communication such that propositions pr, p2, p3...pn are moments of $M$, then $M$ is a unit implying $\mathrm{P}$, that is the set of $\mathrm{pr}, \mathrm{p}_{2}, \mathrm{p}_{3} \ldots \mathrm{pn}$. Given that $\mathrm{M}$ is a greater unit of communication than $\mathrm{P}, \mathrm{M}$ implies $\mathrm{P}$ but is not identical with $\mathrm{P}$, that is to say $\mathrm{M}>\mathrm{P}$, in which '>' expresses implication but not identity. We can thus say that $\mathrm{P}$ expresses or exemplifies $\mathrm{M}$, only if $\mathrm{P}$ is implied in $\mathrm{M}$ in such a way that it exemplifies $M$ in the form of $\mathrm{pr}, \mathrm{p} 2, \mathrm{p}_{3} \ldots \mathrm{pn}$. On the

15 Bernard Bolzano, Grundlegung der Logik (Wissenschaftslehre I/II), edited by Friedrich Kambartel (Hamburg: Felix Meiner, I963), 23. When not noted otherwise, I am responsible for the translations of the original texts. 
other hand, $\mathrm{P}$ exemplifies $\mathrm{M}$, only if $\mathrm{M}$ is not implied in $\mathrm{P}$ otherwise than in the form of pI, p2, p3 ... pn. If propositions are characteristic of $\mathrm{P}$ and if $\mathrm{M}>\mathrm{P}$, then $\mathrm{M}$ is by definition not a proposition, but a message that implies propositions. $M$ as such is thus not propositional but can be exemplified propositionally in terms of $\mathrm{P}$. This point can be expressed with respect to the Christian notion of revelation (CR): if CR is M, CR is not propositional, although it can be exemplified propositionally. To be more precise, $\mathrm{CR}$ is such that it is a set of messages [M] implying $\mathrm{Mr}$, $\mathrm{M}_{2}, \mathrm{M}_{3} \ldots \mathrm{Mn}$, each of which can be expressed propositionally, but none of which is in itself a proposition.

Because of the relationship between first and second order mysteries one can say that divine revelation conceived of in terms of PR cannot be understood, save on the basis of divine revelation understood in terms of the non-propositional dimension of revelation. The conception of $\mathrm{RR}$ refers precisely to that dimension. Thus, any proper propositional investigation of divine revelation presupposes, inasmuch as possible, a proper understanding of $\mathrm{RR}$. If divine revelation is reduced to a merely propositional conception, we may not be able to understand the nature of $\mathrm{PR}$, given that $\mathrm{PR}$ is based on, in the sense of being derivative of, $R R$.

\section{The Bolzano Model of Radical Revelation ${ }^{16}$}

Bolzano's model of divine revelation (hereafter BM) is in many ways close to PR, but, as will be clear, his understanding of divine testimony as the crucial element in BM makes it a version of RR. Testimony or witnessing is a biblical term that Bolzano investigates first in its scriptural background. As he explains, divinely revealed religions, such

${ }^{16}$ Bolzano is well known for his work on the mathematics of infinity. Anton Günther, in the view of some of his commentators the most ingenious Austrian philosopher of the I9th century, was opposed not only to Bolzano, his Prague teacher in philosophy, but also to the emerging Neo-Scholasticism; instead Günther chose a way of thinking that was sharply polemical both with German idealism and the traditional philosophizing in the Church. His publications led to an investigation against him in Rome. After the condemnation of some of his teachings by the Church in I857 Günther withdrew from public life. 
as the religion of Israel and Christianity, always considered themselves as warranted by God's testimony (Hebrew edah [Strong 05713], Greek marturia [Strong 3144]).

Bolzano offers a general and a particular understanding of God's testimony. In the general sense, testimony is defined as follows:

I say [...] that $\mathrm{A}$ testifies to $\mathrm{B}$ a certain belief $\mathrm{b}$, if $\mathrm{A}$ undertakes an action with the definite intention that $\mathrm{B}$, when proceeding in accordance with his best insights, be able to see it as A's will that he accept belief $\mathrm{b}$ on the basis that $\mathrm{A}$ takes $\mathrm{b}$ to be true. ${ }^{17}$

General testimony has several kinds that share the common feature of being expressed in certain characteristic events in the created world. Thus, there are oral and written forms of testimony and even the lack of testimony in the explicit sense of the word may count as God's testimony in a given situation. God's testimony in the proper sense, however, is God's utmost action in which $\mathrm{He}$ testifies His own action in and by the act itself; this Bolzano terms God's authentic action.

God's testimony is what Bolzano takes to be God's revelation (Offenbarung, hereafter R) in the particular sense of testimony. There is an active and a passive sense of God's testimony. Revelation in the active sense is the act of revelation undertaken by a subject in order to express a message to another subject. Revelation in the passive sense is the result of the act of revelation. In Bolzano's definitions, both senses are important, since revelation as an action always results in revelation as an object.

Bolzano's definition of revelation has several steps through which he offers an ever more specific meaning of the term. In its first and general sense, Bolzano defines revelation as follows:

Rr: A reveals or announces belief $b$ to $B$ if $A$ is a full or a partial cause of the emergence of $\mathrm{b}$ in $\mathrm{B} .{ }^{18}$

In $\mathrm{RI}_{\mathrm{I}}$ there is no information as to the exact character of A's revealing $b$ to B. The expression "full or partial cause" refers to the fact that 'revealing'

17 Bernard Bolzano, Lebrbuch der Religionswissenschaft, Vols. I-4 (Stuttgart-Bad Canstatt: Friedrich Frommann Verlag-Günther Holzbog, 1994), I, Io8.

${ }^{18}$ Ibid., I, IO\%. 
may or may not use mediating moments, such as words or other signs. On the other hand, we do not know whether 'revealing' or 'announcing' is an articulately intentional action of $\mathrm{A}$, or if it belongs rather to the nature of $A$ that, inasmuch as it is $A$, it reveals $b$ to $B$.

In $R_{2}$ however we can say with Bolzano that

$\mathrm{R}_{2}$ : $\mathrm{A}$ reveals or announces $\mathrm{b}$ to $\mathrm{B}$ if $\mathrm{A}$ is a full or a partial cause of the emergence of $\mathrm{b}$ in $\mathrm{B}$, and A's action is accompanied by knowledge and will as to its own activity. ${ }^{19}$

$\mathrm{R}_{\mathrm{I}}$ is termed by Bolzano inauthentic revelation; $\mathrm{R}_{2}$, consequently, is authentic revelation. The authenticity of $\mathrm{R}_{2}$ is given in the intentional character of A's revealing $b$ to $B$. A has the intention to reveal $b$ to $B$ in ways that can be mediate or immediate, that is $\mathrm{A}$ can be both a full or a partial cause of $\mathrm{b}$ in $\mathrm{B}$. Bolzano, moreover, emphasizes that the intentional character of A's action is given by both A's knowledge and will, in accordance with Bolzano's understanding of God as possessing these faculties.

So far Bolzano has defined 'revelation' in a general sense; now he turns his attention to divine revelation. $R_{3}$ is for Bolzano divine revelation in the inauthentic sense. Divine revelation in the inauthentic sense is such that God reveals or announces $\mathrm{b}$ to $\mathrm{B}$ in such $\mathrm{a}$ way that $\mathrm{b}$ is unconditionally willed and known by God. That is to say $\mathrm{b}$ is revelation in a general religious sense of the word, inasmuch as b is such as to contribute to the salvation of a certain number of persons. In Bolzano's definition:

$R_{3}$ : A reveals or announces $b$ to $B$ if $A$ is a full or partial cause of the emergence of $\mathrm{b}$ in $\mathrm{B}$, and A's action is accompanied by unconditional knowledge and will as to its own activity. ${ }^{20}$

In the sense of $R_{3}$ all religions are revelations, inasmuch as, Bolzano explains, there is no human or non-human belief that is not some effect of God's will and knowledge. Since 'religion' in Bolzano's understanding is the totality of beliefs (Meinungen) possessed by a human being at any time of his life with reference to his virtue and happiness, so various religions of human history can indeed count as 'revelations' in accordance with $\mathrm{R}_{3}$.

\footnotetext{
19 Ibid., I, IO7.

${ }^{20}$ Ibid., I, II2.
} 
It is however only definition $\mathrm{R}_{4}$ that offers Bolzano's most characteristic understanding of divine revelation. We have divine revelation in the strict sense of the word if and only if

$\mathrm{R}_{4}$ : $A$ reveals $b$ to $B$ if $A$ is the full cause of $b$ in $B$, and A's action is not only accompanied by unconditional knowledge and will as to its own activity, but $\mathrm{A}$ testifies that $\mathrm{b}$ is fully acknowledged and willed by $\mathrm{A}$ in order that $\mathrm{B}$ accepts $\mathrm{b}$ as $\mathrm{R}^{21}$

In contradistinction to the previous definitions, revelation in the sense of $\mathrm{R}_{4}$ is not restricted to being merely an 'announcement'; it can take various forms which we have briefly considered above in connection with the kinds of God's testimonies. The key concept in $\mathrm{R}_{4}$ is indeed 'testimony' which, on BM, is an ultimate concept not to be analyzed in other terms. As Bolzano emphasizes, God's testimony coincides with God's action as to some sort of change in the world. He seems to think that, in certain cases, the absence of an anticipated change (such as the interruption of the Sun's visible movement across the sky) can be seen as a change in the world produced by God's intervention. Bolzano stresses too that God's action is intentional with respect not only to $b$ but also to B's acceptance of $b$ as R. If $b$ entails that $A$ takes $b$ to be true unconditionally and fully, then it follows deontically that $\mathrm{B}$ too takes $\mathrm{b}$ to be true unconditionally. Nevertheless, Bolzano does not raise the problem of the conditions of the subject's understanding of a certain occurrence, physical or mental, as God's revelation.

$\mathrm{R}_{4}$ entails God's authentic action understood as authentically divine revelation accompanied by God's unconditional knowledge and will in order that B accept b as revealed by God. God's testimony, in Bolzano's view, cannot be unconditionally identified either with the existence of Scriptures, or with a series of historic events, such as Christ's life, or even with the magisterium or the sacramental life of the Church. $\mathrm{R}$ is expressed in all of these factors, but it remains, essentially, God's utmost and authentic action-His testimony that makes any of the factors mentioned a moment in $\mathrm{R}$.

\footnotetext{
${ }^{21}$ Ibid., I, II3-II5.
} 
It is important to note that Bolzano applies the then widely accepted distinction between formal and material revelation. ${ }^{22} \mathrm{R}$ is formal if its content, once revealed, can be understood by the human mind in such a way that the content of formal revelation is by itself evident and certain. $\mathrm{R}$ is, however, material only if its content, even if revealed, cannot be fully understood by the human mind. The human being can only accept material revelation 'in faith'.

If I term BM a sort of RR, I refer not only to his understanding of divine testimony, but also to the emphasis on the very fact that there is material revelation. I do not want to deny however that many points in Bolzano's views stand closer to PR than to RR.

\section{The Günther Model of Radical Revelation}

The Günther model of RR (hereafter GM) as put forward in Günther's collected works, can be approached in three ways. ${ }^{23}$ In terms of ecclesiology, Günther holds that RR is factually present in the Church, since the Church is in a way Christ Himself; and while Christ has become invisible after His ascension, there is a visible representative of His person, the visible side of the invisible Christ, namely, the bishop of Rome.

In terms of Christology, RR is fully given in the person of Christ. Christ is the unique, unrepeatable moment not only in the history of humanity, but a fortiori in God's reality itself. Christ is the miracle as such, as Günther holds, who consummated in His person the fullness of R. The structure of GM can be reduced to the simple statement that Jesus Christ embodies and expresses "the fullness of God." (Col 2:9) Günther emphasizes the factual character of the person of Christ; so much so that for him the existence of Christ is the ultimate fact of all possible and

\footnotetext{
${ }^{22}$ Ibid., I, I28.
}

${ }^{23}$ Anton Günther, Gesammelte Schriften, Neue Ausgabe in neun Baenden (Wien, 1882. Unveränderte Nachdruck, Frankfurt: Minerva G.M.B. H., I968). Since Günther's thoughts are not systematically proposed in any of his works, I have also made use of the works of some commentators, most importantly Josef Mader, Offenbarung als Selbstoffenbarung Gottes. Hegels Religionsphilosophie als Anstoss für ein neues Offenbarungsverständnis in der katholischen Theologie des 19. Jahrbunderts (München-Hamburg-London: LIT, 2000) and Joseph Pritz, Glauben und Wissen bei Anton Günther. Eine Einführung in sein Leben und Werk mit einer Auswahl aus seinen Schriften (Wien: Herder I963). 
actual facts. Just as the human being is God's testimony (Gottes Zeugnis) in a certain way, so too Christ is Zeugnis, but infinitely more so than the human being in the created order (Günther, Janusköpfe, II5).

There is a third approach to GM in Günther's writings: the strictly speaking philosophical understanding of divine revelation (Günther, Peregrins Gastmahl, I57 sq.). It is due to Günther's Cartesianism that his starting point is human consciousness, more precisely the kind of certitude given in one's own self-consciousness. Following the Cartesian line of argument, Günther points out that certitude is in the last analysis selfreferring and any heteronomous form of certainty is logically dependent on the former and basic kind. Still, as Günther points out, human certainty can never be absolute. In any act of knowledge, I recognize not only the certainty of my own conscious existence, but also its limited character. I as a conscious being am finite-an insight immediately given together with the insight into the certainty of my own conscious existence. I cannot however recognize the limited nature of my own conscious existence except on the basis of an even deeper insight - given as the third moment in the insight of self-certitude-of the existence of infinity as opposed to my own finitude. Since self-certitude is limited, I recognize that there is an infinite self-certitude in contradistinction to which I recognize my own limited certitude. In other words, Günther holds that it is possible for us to arrive at the recognition of God's infinity on the basis of the recognition of our own finitude. ${ }^{24}$

As Günther writes: "Just as my own knowledge of myself (as an existence for itself) is certain, so my knowledge of God is certain." (Günther, Janusköpfe, 275). Although Günther seems to suggest that the certainty is of the same kind in the two cases (in the case of my own consciousness, and in the knowledge of God), he in fact means only an analogy between the finite and the infinite. The finite character of the human person can be comprehended as given in the inherent process of human consciousness; and that is the process that leads, in the final instance, to the recognition of God's infinity as surpassing my own human and finite existence. ${ }^{25}$

${ }^{24}$ This is clearly Descartes' standpoint too. Cf. Mader, Offenbarung als Selbstoffenbarung Gottes, 285 .

${ }^{25}$ Mader, Offenbarung als Selbstoffenbarung Gottes, 280. 
The finite nature of human consciousness is expressed also in that it becomes realized in three steps or phases. First, the human ego conceives itself as an object. Second, in grasping itself as an object it realizes its subjectivity. And it is in the third step, in the synthesis of its being an object and a subject at the same time, that human consciousness is able to conceive itself as a person. The human person is endowed with the faculties of passivity (mind, Vernunft) and activity (will, Wille) which are united in the substance of the person. In contradistinction to $20^{\text {th }}$ century personalist philosophies, Günther's understanding of the person culminates in the third moment of the process of self-realization, in the synthesis of mind and will. The human person is free, although his freedom is limited like his self-certitude (Günther, Süd-und Nordlichter, I40 sq.).

In considering the logical structure of the three approaches it becomes clear that, for Günther, divine revelation as embodied in the person of Christ is the most important moment. This ultimate fact is the logical starting point for discovering the life of divine reality as it is in itself as well as the life of the human person who, in accordance with the Christian understanding, is made in the likeness of God. We are able to understand human personhood as an image of God, because God made human beings in His likeness. We nevertheless know of God in virtue of the fact of divine revelation, and more particularly in virtue of the fullness of revelation embodied in the person of Christ. At this point it becomes clear again that in Günther's view the philosophy and theology of revelation are fused in a way characteristic of German Idealism.

Thus it becomes possible for Günther to develop his complex model of divine revelation as self-revelation. He distinguishes between internal and external revelation (revelatio ad intra, revelatio ad extra), the former meaning the immanent life of divine reality (Günther, Vorschule I, II2 sq.). The fundamental point is that God in himself is nothing other than self-disclosure, revelatio; divine being is identical with being disclosed or revealed, first immanently in God Himself. Just as the existence of human persons consists in the process of self-realization, via the three phases mentioned above, so too God is self-realization in the ultimate sense of the word, in a sense we are not capable of understanding fully. The way we understand divine self-realization is linear or sequential; still it is a way of conceiving of God's reality. Accordingly, God realizes Himself in the three persons of the Trinity, each of Whom represents a step towards 
His own absolute fullness. The Father is understood thereby as God's self-objectification; the Son as the subjective moment in divine reality; and the Holy Spirit as the synthesis of the two previous moments in God's essence. God as trinity and God as unity coincide fully in God's divine reality; but it can humanly be reconstructed as an infinite process or activity in which the three moments can be distinguished.

God's reality understood as 'revelation' implies no necessary mechanism, but rather absolute freedom; and this understanding is consonant with the traditional Christian thesis that goodness is self-diffusing (bonum est diffusioum sui). ${ }^{26} \mathrm{God}$ is "by His nature" (that is to say in accordance with His absolute freedom) self-revealing. The very basis of self-revelation is God's reality seen as a process of immanent self-revelation. Such a view seems theologically in no way reproachable as Günther emphasizes that the relationship between the three persons and the one divine substance forms an ultimate unity understood in accordance with the traditional Christian conception.

As Günther writes,

I recognize and confess one God in three persons. He is One in His essence or being. He is Three as to the form of His existence. I recognize Him in His one essence, because thinking needs only one being that exists by itself in order to grasp, on the basis of that one being, all other beings which do not exist by themselves. The One, however, is in three Persons, because He as being by itself must at the same time be His own Knowledge by itself. This Knowledge is absolute self-consciousness or absolute self-intuition (Selbstschauung) in such a way that $\mathrm{He}$, while totally emanating Himself, sets His own being against Himself in the total identity (or essential selfsameness) of the one who emanates and the one who is emanated. (Günther, Peregrins Gastmabl, 355).

Günther's understanding of external revelation (revelatio ad extra) follows the Christian understanding in an original way. As opposed to Hegel, who maintained no difference between the internal and the external (historical) life of the Spirit, Günther suggests that it is crucial for Christian philosophy to emphasize the categorical difference between internal and external revelation. God is entirely free in initiating and accomplishing

${ }^{26}$ Cf. "Bonum enim, secundam suam rationem, est diffusivum sui."Thomas Aquinas, ST, I-II q, I a, 4. And see also Bonaventure: "Secundum igitur bonum summe diffusium est sui," Itinerarium, Ch. VI. 
His external revelation, that is to say His primary and secondary revelation. These aspects of revelation are transcendent; they constitute, first, the creation of non-divine reality (primary revelation ad extra), and second, the work of redemption realized by Christ (secondary revelation ad extra). Creation is God's primary external revelation-the center and accomplishment of which is the first human being, "the first Adam." There is again a threefold structure in the primary external revelation that I shall not consider here in detail; suffice it to mention that human beings, as authentic representatives of this kind of divine revelation, are finite manifestations or exemplifications of the structure of God's internal revelation.

As opposed to the "first Adam,"Jesus Christ the "second Adam" is not only the fullness of divine revelation ad extra, but at the same time the fullness of divine revelation. Divine revelation as expressed in Christ can be approached from two angles. On the one hand, the person of Christ represents God's redemptive act, which is to abolish original sin and to restore the initial innocence of human beings. This aspect of divine revelation concerns the dimension of the past. On the other hand, Christ is the manifestation not only of God's external revelation, but also of the internal one such that $\mathrm{He}$ discloses a new moment in divine reality. By assuming human nature, the second person of the Trinity in a way deifies humanity, that is He makes some human persons partake in divine reality in a way that was not possible before the incarnation of Christ. This aspect of divine revelation concerns the dimension of the future.

From the human perspective, it seems that the importance of the secondary divine revelation ad extra consists in the fact that it expresses the dynamism of God's internal life in a particular way. It expresses divine reality as a process of renovation, as it were, in which new moments of God's reality become manifest. The importance of this aspect of secondary divine revelation ad extra can be seen as soon as we consider the future aspect of revelation. Divine revelation, in accordance with the Christian understanding, has not only the aspect of past and present, but that of future too in which the totality of God's reality becomes visible for some human and non-human persons in what is traditionally called the beatific vision. God's self-revelation reaches its full radicalism in that moment, whereas divine revelation is given in its fullness already in the person of Christ. An important point to emphasize: the dynamic 
structure of GM makes the aspect of the future an inherent moment of divine revelation in a way that is not characteristic of BM (Günther, Vorschule $I$, 96 sq.). ${ }^{27}$

Günther distinguishes two conceptions of RR. According to the first, God is self-revealing in Himself and for Himself in His own immanent reality; according to the second, He is self-revealing to the created world in virtue of the incarnation of the second person of the Trinity. Günther attributes the fullness of RR to the second sense of self-revelation; God's self-revelation in the proper sense of the word becomes realized in virtue of the secondary revelation ad extra. The radical character of GM can be sufficiently seen in all these moments; it is not only God's self-revelation that is at the center of GM, but rather the radical self-revelation of God.

Still, God's radical revelation remains a perennial mystery for the human mind. Since the human mind is finite, divine revelation, even if it is received as fully as possible, even if it discloses God's innermost reality, remains a secret. ${ }^{28}$ Divine revelation, we may say, is primarily a mysterium stricte dictum, it is - to use the distinction mentioned in the description of $\mathrm{BM}$ - material revelation in its essence. There is no conceivable proposition, which can fully express, exemplify, or make propositionally clear what God's revelation is in its material essence.

As opposed to BM, therefore, GM is based on the peculiar, redemptive or salvific fact of DR. Philosophical theology is based on the same moment, with the consequence however that there is even less room for the distinction between natural and supernaturally enlightened reason in GM. In this sense, Günther's philosophical theology is more radical than BM. Still, both models share the principle of divine warrant in the context of Church, tradition, and magisterium. Günther's emphasis on DR fits in well with his understanding of philosophical theology as a reflection of objective data; above all the datum of the Incarnation.

In both models, the concept of RR hangs together with the radical character of the respective philosophical theologies. The radicalism of philosophical theology is expressed in Günther's thought in his accentuated anti-Scholasticism. For Günther, it was the all too strong

${ }^{27}$ Günther is convinced that his "speculative theology" is the way in which Christianity as the true philosophy would demonstrate divine truth in its fullness in the future.

${ }^{28}$ Mader, Offenbarung als Selbstoffenbarung Gottes, 268. 
rationalistic tendencies of Scholasticism, which led to the emergence of monistic philosophies in the $19^{\text {th }}$ century. Christian philosophy should overcome, in Günther's view, the monistic tendencies both in scholasticism and in monistic philosophical systems. The only way to reach that objective is the standpoint of a strong metaphysical dualism between the divine and the human. As Günther writes: "My theism is the result of a life-long process in which I have become fully conscious of my own disgust concerning all forms of deification of created beings, all forms of making God and the creature essentially equal." (Günther, Janusköpfe, 4II).

\section{BibLIOGRAPHY}

Avis, Paul, ed. Divine Revelation. Grand Rapids, Michigan: Eardmans, 1997.

Barth, Karl. On Religion: The Revelation of God as the Sublimation of Religion, Edinburgh: T. \& T. Clark Publishers, 2007.

Bolzano, Bernard. Grundlegung der Logik (Wissenschaftslehre I/II). Edited by Friedrich Kambartel.Hamburg: Felix Meiner, 1963.

Bolzano, Bernard. Lebrbuch der Religionswissenschaft, vols. I-4. Stuttgart-Bad Canstatt: Friedrich Frommann Verlag-Günther Holzbog, I994.

Dulles, Avery. Models of Revelation. New York: Orbis, 1992.

Eicher, Peter. Offenbarung. Prinzip neuzeitlicher Theologie. München: Kosel, 1977.

Garrigou-Lagrange, Reginald, O.P. De revelatione per Ecclesiam Catholicam proposita. Torino: Marietti, 1944 .

Günther, Anton. Gesammelte Schriften. Neue Ausgabe in neun Baenden. Wien, I882. Unveränderte Nachdruck, Frankfurt: Minerva G. M. B. H., 1968.

Kant, Immanuel. The Critique of Pure Reason, Chicago: Encyclopædia Britannica, 1952.

Latourelle, Rene. Theology of Revelation, New York: Alba House, 1966.

Mader, Josef. Offenbarung als Selbstoffenbarung Gottes. Hegels Religionsphilosophie als Anstoss für ein neues Offenbarungsverständnis in der katholischen Theologie des I9. Jabrbunderts. München-Hamburg-London: LIT, 2000.

Pritz, Joseph. Glauben und Wissen bei Anton Günther. Eine Einfübrung in sein Leben und Werk mit einer Auswabl aus seinen Schriften, Wien: Herder 1963.

Rahner, Karl. Foundations of the Christian Faith, New York: Crossroad, 1989. 
Schmitz, Josef. Offenbarung, Düsseldorf: Pathmos, 1988.

Swinburne, Richard. Revelation: From Metaphor to Analogy, Oxford: Oxford University Press, 1992.

Swinburne, Richard. Revelation: From Metaphor to Analogy, Second Edition, Oxford: Oxford University Press, 2007.

Ward, Keith. Revelation and Religion, Oxford: Clarendon Press, 1994. 